\title{
The role of social entrepreneurs' cosmopolitan orientation in bridging the gap between prosperity and social deprivation
}

Article

Accepted Version

Mouraviev, N. and Kakabadse, N. ORCID:

https://orcid.org/0000-0002-9517-8279 (2022) The role of social entrepreneurs' cosmopolitan orientation in bridging the gap between prosperity and social deprivation. Society and Business Review, 17 (2). pp. 196-216. ISSN 1746-5680 doi: https://doi.org/10.1108/SBR-02-2021-0033 Available at https://centaur.reading.ac.uk/99568/

It is advisable to refer to the publisher's version if you intend to cite from the work. See Guidance on citing.

To link to this article DOI: http://dx.doi.org/10.1108/SBR-02-2021-0033

Publisher: Emerald

All outputs in CentAUR are protected by Intellectual Property Rights law, including copyright law. Copyright and IPR is retained by the creators or other copyright holders. Terms and conditions for use of this material are defined in the End User Agreement. 


\section{www.reading.ac.uk/centaur}

\section{CentAUR}

Central Archive at the University of Reading

Reading's research outputs online 


\title{
Nikolai Mouraviev and Nada Kakabadse
}

\section{The role of social entrepreneurs' cosmopolitan orientation in bridging the gap between prosperity and social deprivation}

\section{Accepted for publication in Society and Business Review 29 July 2021}

\begin{abstract}
Purpose - Israel is characterised by economic growth that is accompanied not only by prosperity, but also increasing poverty. The paper aims to conceptualise the role of Israel's social enterprises in reducing the gap between prosperous and disadvantaged populations.

Design/methodology/approach - This qualitative study is based on 23 in-depth interviews. It makes use of a theoretical framework that incorporates two elements: cosmopolitanism and social entrepreneurship. Cosmopolitanism, together with government policies that aim to develop free enterprise and international trade, support entrepreneurship, and advance education, accompanies and facilitates prosperity. While prosperity increases inequality, social entrepreneurship develops as a tool to mitigate the side effects of economic growth in the form of the increasing gap between the rich and the poor.

Findings - This paper argues that the principal reason why the gap evolved and is increasing is in the discrepancy between rapidly rising requirements presented by the innovationfocused economy and the workers' skills. Based on interviews with social entrepreneurs who are (co)founders or managers of businesses with a social purpose, findings show that the gap between prosperity and social deprivation could be bridged by increasing workers' capacity to align their skills with employers' requirements, which is the area to which Israeli social enterprises contribute.
\end{abstract}


Originality - The paper argues that cosmopolitan orientation is one of the contributors to economic growth and innovation, while prosperity increases the gap between high- and lowincome groups. The paper contributes to the body of knowledge about social entrepreneurs by applying the framework that makes use of cosmopolitanism as an important driver of Israeli social entrepreneurship, which helps to explain the role that social business enterprises play in reducing the gap between prosperous and disadvantaged populations.

Keywords: Cosmopolitanism, Social enterprise, Israel

Paper type: Research paper

\section{Introduction}

Israel's remarkable progress in many fields - science, technology, innovation, education, pharmaceutical industry, and health care - triggers researchers' interest in relation to enablers of this success as well as impediments and spillover effects (Roper and Grimes, 2005). Formed in 1948, the nation experienced significant political, economic, and social transformation and underwent changes from a welfare state with extensive government regulation to a liberalised market-driven economy (Gidron et al., 2004). Focusing on innovation and fostering entrepreneurship, the country achieved considerable economic growth, higher income levels and living standards for many; contrastingly, this pathway to prosperity was also accompanied by increased unemployment and overall social deprivation for others (Roper and Grimes, 2005). Israel earned the nickname of a "start-up nation" as, with a population of 9 million, it has the largest number of start-ups per capita in the world: around one start-up per 1,400 people (Reed, 2015).

According to the International Monetary Fund (IMF) database, Israel's GDP was USD 41.5 billion in 1985 and steadily grew to 337.4 billion in 2018 (IMF, 2021). Yet, during the 
same period of economic growth, the gap between prosperity and poverty has widened. Since the mid-1980s, Israel has had the highest levels of disposable income inequality amongst the Organisation for Economic Co-operation and Development (OECD) countries, and only since 2016 has it been surpassed, by the United States (Dahan, 2017; Waksman, 2018). The gap between high- and low-income groups and the increasing marginalisation of certain populations has become an ongoing problem embedded in the fabric of Israeli society (Abbou et al., 2017). The main trends in Israeli disposable income inequality lie in the decline in the share of the middle-wage earners, the growing prevalence of part-time jobs at the lower end of the labour market, and the increased concentration of income at the high end of the labour market (Cornfeld and Danieli, 2015).

For example, according to data from the CIA (2014), Israel's Gini Index (measuring the degree of inequality in the income distribution of a country's population) was 42.8 , where a score of 0 is perfect equality. The number of average salaries to buy an average home in Israel rose from 103 monthly salaries in 2008 to 135 salaries in 2013, whilst in the UK it takes 73 salaries, in the US it takes 60, and 30 in Sweden (Malul, 2018). Housing affordability is lower than in other OECD countries, particularly for low-income households (OECD, 2020). Of the 1.8 million Israelis living below the poverty line, a vast number 841,000 - are children (Shaoul, 2020). The share of the working poor (as proportion of people who are considered poor) is also high at around 13 percent in comparison to 11 percent in the USA, 7 percent in the UK and 3.9 percent in Finland (OECD, 2020). Poverty in Israel remains among the highest in the OECD countries (OECD, 2020). While productivity in the high-tech sector is high compared with other countries, the more traditional sectors lag significantly behind (OECD, 2020).

It is not uncommon for prospering countries to experience an increase in poverty, often caused by long-term unemployment, the rising prices of essential goods (including food), 
immigration, or wages that do not track the rising cost of living. Prosperity has not always been equally distributed, as is the case in Israel, and it is often accompanied by growing poverty. Although social entrepreneurship in Israel emerged, in part, as a response to this phenomenon, certain questions need to be answered, particularly about the nature and conceptualisation of the growing gap between the rich and the poor (i.e. why exactly it evolved); the role social business enterprises (SBEs) can play in resolving it; what conditions these enterprises operate in; and what impediments they experience on the way to making their contribution to solving social problems. Israel is one of the world leaders in science, technology, and innovation (Daniely, 2020) and, therefore, SBEs may also show the same trend; Israel is ranked number one in the world for investment in research and development (World Economic Forum (WEF), 2020). Israel is the third most educated country in the world, according to 2017 data compiled by the OECD, with 50.9 percent of citizens aged 2564 holding a degree in higher education, whether academic or vocational (OECD, 2020).

By using a framework that incorporates two elements - (a) cosmopolitanism that, alongside other factors, such as government policy of liberalisation the economy, support to entrepreneurship, and advancement of education, accompanies and facilitates economic growth and (b) social entrepreneurship - this paper's aim is to conceptualise the role that SBEs play in reducing the gap between prosperous and disadvantaged populations.

It is worth noting that while cosmopolitanism was used as an anti-Semitic slur in the past (e.g. by the Nazis), this paper's use of the term is purely as an academic concept, as explained in the first subsection of the theoretical framework.

The paper intends to answer the following research questions:

1. How do actors in SBEs perceive the gap between prosperity and social deprivation in Israel in light of the nation's cosmopolitan orientation?

2. How do actors in SBEs perceive their ability to bridge this gap? 
3. What conditions, as perceived by actors in SBEs, are required to ensure SBEs' effective contribution to reducing this gap?

The unit of analysis is a social entrepreneur (SE) that in this study is represented by an individual who is a (co)founder or a manager of an SBE.

The paper is organised as follows. In the next section, the paper's theoretical framework is delineated, followed by a section on the methodology. The subsequent three sections provide details of the conditions in which the Israeli economy operates, how deprivation began evolving, and the legal and governance aspects of SBEs in the country. The study's results are then outlined and discussed. The final part draws further insights into the findings by revisiting the theoretical framework and presents conclusions. We conclude the paper by delineating contributions of the study, its limitations, and making suggestions for future research.

\section{Theoretical framework}

The study's theoretical framework rests on two concepts/theories: cosmopolitan orientation that, alongside other factors, accompanies and facilitates economic growth, while growth increases the gap between prosperity and deprivation (Mouraviev and Kakabadse, 2016) and social entrepreneurship (Borzaga and Defourny, 2001) as a tool to mitigate the side effects of economic growth (Mouraviev and Kakabadse, 2019). Putting the two concepts together, the study views cosmopolitan focus as one of the drivers, alongside other enablers, of Israel's growth and prosperity. Cosmopolitan orientation emerged alongside economic growth and, in part, facilitated it. At the same time growth was accompanied by the increasing gap between the rich and the poor, and cosmopolitanism triggered the emergence of social entrepreneurship. In 2018, some 26 percent of Israeli households lived in poverty. The depth of poverty has also grown, with poor families living on average 32 percent below the poverty 
line (NII, 2018; Shaoul, 2020). This makes Israel 10 percent higher on the Gini index of income inequality than the Organisation for Economic Co-operation and Development (OECD) average (Shaoul, 2020). To understand the nature of this phenomenon and how it could be explained, the framework incorporates the perspective of SEs as one of the tools to reduce poverty. Figure 1 provides highlights of the study's theoretical lens. The details are discussed below.

< INSERT FIGURE 1 ABOUT HERE >

\section{Cosmopolitan orientation as a feature of an open society}

The concept of cosmopolitanism has its origins in ancient Athens. Cosmopolitanism had undergone many reinterpretations throughout history, receiving particularly negative connotations in the early 20th century, gaining a pejorative meaning of rootlessness, nationlessness and non-belonging (Bohm-Duchen, 2013). Re-emerging as a positive concept after World War II, most recently it has been reinvented for the global age, emphasising the interconnectedness of all human beings. For many, cosmopolitanism is no longer an idea but rather the substance of social reality (Sznaider, 2007). Cosmopolitanism is the idea that the universal and the particular must in a way both be preserved, without either being reduced to the other (Arendt, 2007; Sznaider, 2007). Israeli cosmopolitanism in practice is both universal-democratic and particular-Jewish state. Hence, the universality is "inherently limited, meaning that it is not a universal democratic state (if one ever existed)" (Sznaider, 2010: 2), with a policy of "thinking globally, acting locally" (Gappert, 1989: 321). The theoretical framework makes use of a range of concepts that underpin cosmopolitanism and are applied to entrepreneurship (Douzinas, 2007; Woodward et al., 2008; Drori et al., 2009; Honig et al., 2010). Characterised by their belonging to the wider world, rather than to a 
certain locality (country or city), cosmopolitan entrepreneurs share a number of similarities including their attitudes, values, and behaviours. Entrepreneurs' cosmopolitan orientation is demonstrated in a variety of ways, known as having a cosmopolitan disposition (Bourdieu, 1984). The principal features of entrepreneurs' cosmopolitan disposition are acceptance of diversity, social inclusion, equality, and tolerance, as well as active opportunity identification, mobility, and innovation (Anderson et al., 2010).

Disposition does not evolve by itself or as a result of an individual's preferences (De Clercq and Voronov, 2009). The literature shows that social structures can form and shape dispositions (Skrbiš and Woodward, 2013; Mouraviev and Kakabadse, 2016). With this in mind, it is worth emphasising the Israeli government's strong cosmopolitan orientation in its economic policy and support rendered to entrepreneurship (Kakabadse and Mouraviev, 2019).

Cosmopolitan orientation emerged in the process of Israel's economic growth as a feature of an open society that encourages international co-operation and making use of ideas and technology available across the globe. At the same time, cosmopolitanism, with its embedded openness and innovation, attracts talent, networks and funding from around the world. Owing to this, it has also become one of the drivers of economic growth, together with many other enablers, such as government policy aiming to develop free enterprise and international trade, support to entrepreneurship, and advancement of education. The same model can be seen across the globe, e.g. in some urban areas including Auckland, Dubai, New York, Shanghai, and a few other prosperous cities (Mouraviev and Kakabadse, 2019). Tel Aviv is also a good example of a large metropolitan area that enjoyed growth and sustainability, in the form of economic durability, owing, in part, to its cosmopolitan orientation actively practised by the nation's entrepreneurs and their global networks. 


\section{Cosmopolitan orientation as an enabler of growing poverty}

Cosmopolitanism also significantly raises requirements for human resources in terms of their qualifications, skills, innovative thinking, initiative-taking, and enterprising behaviour (Skrbiš and Woodward, 2013; Mouraviev and Kakabadse, 2019). Those who do not reach the required standard are highly likely to remain outside the requisite scope of skills that companies, driven by cosmopolitan orientation and focused on innovation, are looking for. These individuals, therefore, may become jobless or may find themselves in low-skilled (and low-paid) jobs, or may otherwise join the ranks of deprived populations. Therefore, although Israel's cosmopolitan orientation has been a contributor, among others, to the nation's economic growth through promotion of innovation and advancement of human capital, it has also contributed to growing poverty. Increasing social deprivation of certain populations has become a commonly shared concern (Gidron et al., 2013).

An indication (although indirect) of the growing discontent with poverty and deprivation is migration out of the country. In recent years, the number of Israelis leaving the country for an extended period became higher than the number of those coming to Israel. In 2015, approximately 16,700 Israelis left the country to live overseas on a long-term basis, mostly with their families, while only about 8,500 returned after living abroad for at least a year (Dattel, 2017)

However, can cosmopolitanism and innovation-focused entrepreneurship take the full blame for growing poverty? Is lack of demand for low-skilled workers, which leads to their increasing unemployment and deprivation, an engrained feature of innovative entrepreneurial firms and, more generally, of economic growth? Extended to the social sciences, a theory of organisational paradox emphasises asymmetry between an individual's capacity to perform well in a job and expectation (Plotnitsky, 2013; Cuonzo, 2014; Hahn and Knight, 2019; Li, 
2020). The theory contends that the key is to reduce the asymmetry by either increasing one's capacities or decreasing one's expectations, or doing both simultaneously (Li, 2020).

\section{Role of social entrepreneurship}

Finally, consideration of the role played by SBEs was included in the theoretical framework. This is because Israel's economic growth was accompanied not only by the increasing gap between the rich and the poor, but also by the expansion of entrepreneurship with the social purpose. This paper views an SBE as a company doing business and looking for profit so that it can be used for its own development and for financing its socially focused activity, whereas the social mandate is clearly stated in the company's mission, bylaws, and/or other documents (Bacq and Janssen, 2011). While SBEs create value for society, what are the links between growth, SBEs, and social deprivation? This study intends to look at this question by establishing the connections between the elements of its theoretical framework.

\section{Methodology}

In keeping with the aim of obtaining insights into how SBEs could bridge the gap between Israel's prosperity and social deprivation, an exploratory qualitative method was adopted for this study (Lincoln and Guba, 1985). We adopted purposive and chain referral strategies to select participants for the study. The purposive sampling technique, also known as judgment sampling, "is the deliberate choice of a participant due to the qualities the participant possesses" (Etikan et al., 2016: 2). In this study, social entrepreneurs who are (co)founders and/or managers of their businesses were selected as they are the main decision-makers and their actions can contribute to bridging the gap between prosperity and deprivation.

In addition, a chain referral, also known as snowballing technique, was used as a sampling method (Atkinson and Flint, 2004; Kakabadse et al., 2015), which employs link 
tracing where the inquirers receive recommendations from one interviewee on further potential social entrepreneurs who might agree to be interviewed as well. By asking openended questions in semi-structured interviews, responses may more accurately reflect study participants' actual thoughts and experiences, and may be less subject to biases (Flick, 2018).

Potential participants were approached by the inquirers making use of their own network, as recommended by Miles and Huberman (1994). We commenced our inquiry with the eight people from our social network and then followed up on their recommendations. All participants who agreed to be interviewed were asked to facilitate access to other prospective participants, that is, to entrepreneurs running a business with a social purpose, whereby the contacts snowballed. Most were happy to introduce the inquirers to two or three other social entrepreneurs from their network. Interviews mostly took place at the participants' workplace or in coffee shops and lasted 60 to 70 minutes each. Data collection and analysis were carried out concurrently in order to seek information/data on any new and relevant themes emerging from the analysed data (Singh et al., 2011). Data collection continued until data saturation was reached, as recommended by Blaikie (2009). In order to protect their identity, Table 1 presents only the basic attributes of the study participants.

Table 1. Interviewee attributes

\section{< INSERT TABLE 1 ABOUT HERE >}

The respondents were mainly driven by ideological rather than economic motivation to cofound or manage an SBE. In addition to attending mandatory military training, almost all participants since their youth were involved in various leadership training, youth movements, and other group activities that nurture both the ideology and leadership skills that are needed for social entrepreneurship (Gold, 2001). For example, most Israeli children join a local youth 
movement, each with its own philosophy (e.g. political, religious, or both). These are not just programmes, but movements with a mission to promote social action or change. Students usually begin attending activities when they are in the 4th grade, and whilst in high school many students become movement leaders (Gold, 2001; Cohen and Katz, 2016). Moreover, nearly all young people, both male and female (except for Ultra-Orthodox, Pacifists, and Arabs) at the age of 18 enter the Israel Defense Forces (IDF) (Bar-Shalom and Sarel, 2011; Cohen and Katz, 2016; Cohen et al., 2019). The length of service for women is usually about two years and about three years for men. The IDF is one of Israeli society's leading institutions, influencing the country's economy, culture, politics, as well as contributing to developing a well-educated society and workforce (Reed, 2015). For example, IDF's cyberintelligence agency - Unit 8200 (shmone matayim) - which trains young Israeli recruits in coding, hacking and cyber-espionage, as well as in developing smartphone apps, is "the foremost technical intelligence agency in the world and stands on a par with the NSA in everything except scale" (Reed, 2015: 2). These characteristics are largely unique to the Israeli context (Cohen et al., 2019).

\section{Data analysis}

During data collection, all 23 interviews were digitally recorded, transcribed, and manually coded in order to identify emergent codes, thus allowing codes to fit the data, rather than trying to make the data fit pre-determined codes (Lofland, 1971; Bogdan and Bilken, 1982). The interview transcripts were then coded one by one using first-order (open) and secondorder (axial) coding (Miles and Huberman, 1994; Strauss and Corbin, 2008). The initial coding (or open coding) stage sought insights into the most frequently repeated words, word combinations, and notions, such as growing deprivation, motivation, and cosmopolitan orientation, some of which later found their place in the theoretical framework. This resulted 
in 30 first-order codes that were then drawn upon to create the second-order codes. Data saturation was reached after 19-20 interviews when no new data were reported in subsequent interviews. Table 2 shows examples of how the themes were distilled from the interview data.

\section{< INSERT TABLE 2 ABOUT HERE >}

Through several iterations of axial coding (i.e. relating codes to each other) (Strauss and Corbin, 2008), the aggregated codes were constructed, which allowed us to identify the following three themes:

Theme 1: The links between cosmopolitan orientation, growth, and social entrepreneurship. Theme 2: Can SBEs bridge the gap between the rich and the poor? Theme 3: The SBEs' role in solving multiple problems in society.

Before we report the study's findings in each theme and offer a discussion, the next three sections provide context by explaining conditions in which the Israeli economy operates, showing how deprivation began evolving and highlighting the status of SBEs in the country.

\section{Background to the Israeli economy}

The State of Israel was established on social ideology, although the government never had any sizeable ownership of means of production. While the central government adopted a welfare state framework and assumed responsibility for the welfare of its citizens, at the end of the 1950s and in the mid-1970s, there was a move towards cooperation with the private sector and gradual liberalisation of the economy (Gidron, 2004).

In 1977, with the ascendance of the right-wing Likud Party, Israel experienced the beginning of political transformation in the form of the first steps towards a free market economy (Abbou et al., 2017). The crises in the early 1980s and the whole cooperative 
movement brought about a collapse of the collaborative system and initiated a gradual adoption of the alternative, neo-liberal ideology as an organising principle of economic and social management (Gidron, 2004). 1985 marks a turning point in Israel's economic history. Led by the national unity government (Labour and Likud parties), policy focused on stabilising a failing economy suffering under the 400 percent inflation rate (Ben-Zion, 2005). During the period 1985 to 2000 , the government's attempt to stabilise the economy was marked by a shift to a free-market economy and reduced government intervention (Ben-Zion, 2005; Abbou et al., 2017). Many government-owned companies were privatised, and government expenditure on education and health contracted.

Despite a range of difficulties, Israel's economy has developed several fundamental strengths, including a large high-tech sector and largely educated workforce. Over time, Israel has established itself as one of the world's leaders in science, technology, and innovation. According to the Global Competitiveness Report 2026-2017 (WEF, 2017), Israel is the second most innovative country in the world. The nation heavily invested in science and technology, with its commercialisation helping to secure a top position in innovation (Senor and Singer, 2009). A world-class, export-focused, high-tech sector - specialising in computer hardware and software, medical technologies and pharmaceuticals, supported by the ease of access to venture capital - significantly contributed to steadily higher rates of gross domestic profit (GDP) growth (Roper and Grimes, 2005; Mouraviev and Kakabadse, 2019). Furthermore, this growth was accelerated by active entrepreneurship evidenced by the country's number of start-up companies per inhabitant being one of the largest in the world (Senor and Singer, 2009). However, the number of those living in poverty also increased (Marom, 2013; Abbou et al., 2017).

\section{Increasing social deprivation}


In summer 2011, Israel was swept by a wave of political protests as multiple encampments occupied streets and weekly mass rallies were held, emanating from Tel Aviv to nearly 60 cities and small towns (Marom, 2013). The protest initially reflected a specific urban context: the lack of affordable housing in Tel Aviv (Marom, 2013). The 2011 social protest set the ground for changes in the socio-economic sphere, emphasising the need for people and organisations to create solutions that would lead to a better society. Young people asked, 'why can't young couples even dream of buying a house and certainly not in the centre?'; 'why is the city we love becoming for rich only?' (Leef, 2011: 1). The protest highlighted Israel's systemic socio-spatial inequalities (Tzfadia and Yacobi, 2011).

Housing affordability was among the most striking of inequalities (Marom, 2013). Ratios such as housing price to income, housing loan repayment to income, and ongoing housing cost to income were among the highest in the world at the beginning of the last decade (Marom, 2013). Another deep concern was high food prices (Marom, 2013). In Israel, poverty is strongly concentrated in particular populations: ultra-Orthodox Jews and Israeli Arabs (Ben-Porat, 2013; Malach and Cahaner, 2019). Among the 20 percent of the population who are Arab-Israelis, the poverty rate is around 50 percent. Among the (estimated) 7 percent who are ultra-Orthodox Jews, the poverty rate is around 60 percent (Ben-Porat, 2013). Both populations share the same immediate causes of poverty: low employment rates, low wages, and large families (OECD, 2020).

Israel's third sector provides assistance to disadvantaged populations (Abbou et al., 2017). The sector includes non-profit organisations and public benefit companies (PBCs) and is dependent on government financing and donations from private persons, businesses, and from abroad (Gidron et al., 2004).

\section{Rise of the fourth sector: social entrepreneurship}


In response to growing social deprivation, the fourth sector - SBEs - developed in the country. Influenced by social protests against growing inequality and poverty, some Israeli entrepreneurs applied their skills not for the pursuit of own gain, but for providing benefits for communities and society at large (Svirsky, 2013).

SEs emerged in Israel in 2000 (Gidron and Abbou, 2012), with many more of them forming following the 2011 protests with the aim of addressing social problems. While business entrepreneurship often creates social value as a by-product of the economic value, in social entrepreneurship generating economic value is a means to achieve the social value (Martin and Osberg, 2007). Thus, the main criteria for success for business entrepreneurs are financial, while for the social entrepreneur it is creation of social change (Dees, 2003). Social entrepreneurs are characterised as opportunity-seeking individuals who aim to meet unsatisfied and often critical needs by using resources to achieve sustainable and systemic social change (Thompson et al., 2000; Dacin et al., 2010).

Much of focus of Israel's SBEs was on providing employment and inclusion for marginalised populations - mainly disadvantaged youth and populations coping with disability - as well as on environmental issues (Gidron and Abbou, 2012). As for legal forms of social enterprises in Israel, they are usually registered as social businesses (SBs) and are typically established by one or two entrepreneurs, financed by their capital, based on a consensual model, which is more relevant to non-governmental organisations (NGOs) and cooperatives (Borzaga and Defourny, 2001).

The SB type of SBE is a standard business company, but with a stated social mission. It is usually small, employing between 10 and 25 staff (Gidron and Abbou, 2012). As SBs lack formal public support, many social entrepreneurs opt for the legal status provided by NGOs. Another alternative legal status for an SBE is a cooperative. Although cooperatives have varying governance structures, for the most part they do not rely on philanthropic grants or 
government support; rather, they are financed by their own income (Rothschild, 2009). SBEs in the form of SBs and cooperatives are yet to gain trust in their operations from society and government support in the form of clear policy. Characteristics of the SBE forms are summarised in Table 3.

Table 3. Three forms of Israeli social business enterprise

< INSERT TABLE 3 ABOUT HERE >

\section{Results and discussion}

Theme 1: The links between cosmopolitan orientation, growth, and social entrepreneurship

In the first theme, interviewees acknowledged the problem - the growing gap between Israel's rich and poor - and linked it with the nation's enterprising character and the country's capacity to find solutions. Interviewees emphasised that the rising poverty level is associated with the country's economic growth and prosperity. In the words of one interviewee:

Although the overall standard of living has risen, on average, so has the gap between the rich and the poor. (Interviewee 3)

This view is shared by another respondent:

Since the move to a free-market economy in the mid-80s, we have become less, rather than more, equal. We are innovative, technologically savvy, and able. Yet, many people are deprived and poor. We are cosmopolitan, and we are local. Being a cosmopolitan social entrepreneur does not mean that we forget our ethnic bonds. (Interviewee 7) 
The majority of interviewees underlined that the concerns about higher levels of poverty are widespread, rather than concentrated in the country's main urban areas or small towns. This is evidenced by the following comment:

We are all aware of the problems. The protest of 2011 articulated a wide range of social, economic, and political concerns of residents of the cities as well [as] of smaller suburban satellites and peripheral towns. (Interviewee 23)

Study participants were also confident, although at the level of patriotic feeling, that the country is capable of effectively dealing with poverty and finding solutions that would combat growing income inequality. One interviewee argued that:

We are survivors, innovative, and community-oriented. We have solved the water problem, the Watergen (drinking water produced from thin air) and Netafim (a desertfriendly irrigation system). We created the world's first USB drive and Waze - a navigation application. We must be able to solve our social problem. We are a tiny country with an innovative and cosmopolitan mindset that keeps us connected to the wider community. (Interviewee 14)

The same view is supported by another interviewee:

We are an entrepreneurial nation. We have capabilities and passion for facing the problems and for accepting responsibility for creating our solutions. We have overcome many adversities. We highly value the delivery of Jewish friendships as an explicit act of Jewish education which we provide here and internationally. Jewish education nurtures the power of Jewish social networks to express and sustain various forms of Jewish community involvement. Much of our achievement comes from our local innovation and diaspora dedication. We are a cosmopolitan nation. (Interviewee 17) 
Another participant connected the capacity to deal with all kinds of problems, including social, specifically with entrepreneurship and innovation, rather than with the general perspective on Israel as an enterprising nation, stating:

Problems and uncertainty are central to entrepreneurship, yet we innovate and see opportunity in solving these problems, whether these may be a process, product, environment or social problem. We have a large network with international diaspora, which provides a mixture of gifts and a bit of investment, which in turn facilitates international cooperation between various groups. Our network helps us grow, creates innovate solutions for our clients and strengthens cosmopolitan orientation. (Interviewee 21)

To summarise, rising poverty and the gap between income levels were overwhelmingly recognised as legitimate concerns by the study participants. They also instantly, without any doubt, argued that the nation is able to find plausible solutions to these problems, and linked the country's perceived ability to deal with any kind of problems with innovation, people's enterprising behaviour, and entrepreneurship. The interviewees' opinions and their high levels of confidence were aligned with how they referred to who exactly is able to deal with the problems. In their narratives, they consistently used 'we', rather than 'the government', which suggests that they viewed themselves as active members of Israeli civic society and that citizens' voices are heard. They viewed themselves as actors capable of solving the issue of poverty and pursuing the interests of society (Cohen, 1995).

Many interviewees emphasised how Israel's economic growth is a result of the nation's cosmopolitan orientation and innovation, at least in part, which is also confirmed by Kakabadse and Mouraviev's (2019) study. Interviewees also linked the capacity to innovate with support of the Jewish diaspora, particularly from the USA and Europe. While growth was driven, in part, by cosmopolitan orientation, it appeared that increasing poverty was/is an 
unintended side effect of cosmopolitanism. Interviewees appreciated cosmopolitanism as one of the factors, alongside other drivers, of economic growth and active entrepreneurship in which they became successful, so that they could then incorporate socially focused projects in their work. Nonetheless, interviewees overwhelmingly acknowledged a contradictory situation: growth is typically accompanied by prosperity, but in the case of their nation it was also accompanied by increasing poverty ( $\mathrm{Li}, 2020)$.

Many interviewees confirmed an intent to identify a sustainable way of solving social problems. This is exemplified in the following excerpt:

In July 2011, I took part in the "tents" protest, which was about housing. I don't know when exactly, but during these two months of protest, I realised that the people's powerlessness needs to be transformed into empowerment. That is when I decided to go back to my roots, I was raised in a kibbutz. And I started this cooperative project. (Interviewee 8)

The above quote shows intent and the underlying motivation to find a solution that brings sustainability, which was echoed by most interviewees. The commonality between the interview excerpts clearly shows that launching an enterprise with a social mandate was viewed by the study participants as a way of making money that would allow for removing or at least significantly reducing the dependency on donations and increasing focus on social goals. These comments resonate with Levy's (2001) argument that recipients of philanthropic aid become reliant on the private sources of funding, which is subject to uncertainty as donors often change their funding priorities.

\section{Theme 2: Can SBEs bridge the gap between the rich and the poor?}

In conditions where SBEs are yet to become common and broadly accepted as part of a functioning society, a large number of interviewees focused on the business side of an SBE 
as, without profit-making activity, a social purpose cannot be served. Securing initial funding to get started with a profit-generating project is an often difficult but common task, which frequently becomes an obstacle for aspiring entrepreneurs regardless of the strength of their motivation. This is confirmed by the following two comments:

Attracting initial seed money is always challenging. Social entrepreneurs seek growth or require support by capital. (Interviewee 23)

There is always a need for seed money. You need start-up money to start a social or any other type of enterprise. (Interviewee 18)

In this theme, all interviewees were very positive about the ability of SBEs to solve society's problems caused by income inequality. In their comments, interviewees pointed out a few critical conditions that would ensure the growth of social entrepreneurship and, therefore, its contribution to society. One condition refers to interviewees' conceptualisation of social entrepreneurship, particularly that an SBE should not be viewed as an 'add-on' or as an enterprise launched regardless of any underpinning business ideas. In the interviewees' opinion, an SBE is a company that is launched by entrepreneurs as a reflection of their understanding of society's needs. Two comments exemplify this:

Our aspiration is to bridge the prosperity-poverty gap. But to succeed, we need to transform the social sector, to allow the emergence of entrepreneurs from within. Yes, I became a social entrepreneur from necessity and now can help others. (Interviewee 7) The short answer [to the question whether SBEs can bridge the gap between the rich and the poor] is yes, provided that we can create an effective system to support social entrepreneurship. We need social policies that promote entrepreneurs from their own ranks and also attract new capital on a large scale. (Interviewee 11)

An additional condition that would allow SEs to contribute to poverty reduction refers to attaining a critical mass of these enterprises. Looking at the future, the study participants 
clearly viewed SBEs as an established and large sector of the Israeli economy, which reflects their aspirations, as the following excerpts show:

Once a social enterprise achieves significant scale, then we will be able to reduce the gap. (Interviewee 12)

Bridging the gap needs more than just a few enterprises. There should be a growing number of social entities. It requires a real movement that can link the social sector to the capital markets and introduce new financial instruments that will enable entrepreneurs to make a significant social impact while making adequate financial returns to their investors. (Interviewee 9)

Yet another condition to ensure the growth of SBEs and their effectiveness is an initial investment that would allow SBEs to launch and establish their profit-making business. In part, the search for investors is a response to the Israeli policy of funding the third sector, which suffers from notoriously overcomplicated bureaucracy (Almog-Bar, 2016). The system was/is based on a mixture of protocols and agreements resulting from political pressure, without distinct philosophy or ideology (Gidron et al., 2004). Furthermore, political pressure is exerted on the national, ministerial, and local levels, which results in a negative impact on overall funding for the sector (Gidron et al., 2004). With this in the background, it is not surprising that interviewees emphasise the role of private investors as follows:

In addition to social entrepreneurs, we also need investors to make a social impact. Only then we will significantly fill the gap between social needs and currently offered provisions by the social sector and government. (Interviewee 16)

Possibly, but we need to link the private sector, such as enlightened venture capital investments, with social enterprises in order to run programmes that address social problems, such as dealing with reoffending youth or skills building. The success of such programmes can significantly alleviate the future burden on the government and social 
sector, as these can pay investors a return-on-investment fee for having achieved improved social outcomes. (Interviewee 19)

The comments above show that the interviewees do not view initial funding for SBEs as a donation or a charitable act by whoever wishes to contribute to society's welfare. SEs require an investment, typical for any business, in which an investor accepts risk and wants to be compensated for this risk by receiving a return on investment. This means that in its financials, an SBE has to allocate part of the profit to an investor, while another part could be used for social purposes. The following comments highlight the government's role and explain that, ideally, the development of social entrepreneurship should be ensured by the ecosystem that would include many actors working together. In the interviewees' opinions, the ecosystem, driven by innovation, is an overarching (and all-embracing) condition that would make social entrepreneurship effective.

We need to transform the social sector and create a new balance between the roles of the government, the capital markets, and citizens. I think that all organisations need to be socially and environmentally responsible. Only then we will be able to bridge the current gap. We need investors that desire to see the social impact made by their investment. So, we need our government, corporations, investors, and philanthropic donors to be engaged, to various degrees, with social enterprise. Only then we can close this gap. (Interviewee 20)

We can solve this problem but not alone. The government needs to play ball. Policymakers need to provide necessary non-financial initiatives, which can benefit the social enterprise. We also need socially conscious investors that in addition to making money want to improve society. (Interviewee 17) 
We are a small but growing sector, with limited resources, but we innovatively use these resources. We provide office space for a small fee to start-up entrepreneurs who otherwise could not afford to have an office in the city. (Interviewee 21)

The above three excerpts show the need to attract the investors who are not only looking for profit-making opportunities but are also interested in contributing to social welfare. This might mean that some investors may be willing to sacrifice part of their return in favour of a socially focused part of an SBE. By doing this, they would make a larger share of profit available for the SBE, which could be used for strengthening the venture and/or expanding its social activity. In addition, socially conscious investors might be able to contribute to social entrepreneurship by sharing their managerial, logistical, and technological expertise. Social value creation involves 'improving the well-being of disadvantaged individuals' (Kroeger and Weber, 2014: 514), and is continuously weighed against the required costs (Quelin et al., 2017), where the investors' costs need to be factored in.

These interviewees also called for an active government's role, suggesting that policymakers need to look at the need to change policies and regulations pertinent to the social sector and how poverty problems are handled. This is yet another perspective on designing the ecosystem for social entrepreneurship, in which the government should, in the interviewees' opinions, play a key role. However, interviewees did not attribute the responsibility to develop SBEs exclusively to the government and investors. Working together by involving multiple actors at all levels and from all kinds of organisations is perceived by interviewees as a countrywide task. This is yet further proof that the study participants view bridging the gap between the rich and the poor as the nation's problem, the solution for which everyone needs to contribute towards, rather than pointing to certain actors (e.g. the government or large corporations) to take responsibility. In addition, innovation was noted a number of times as a tool that underpins all SBEs' activities, which could be viewed 
as a reflection of limited resources and the need to combine profit-making and the social focus.

\section{Theme 3: The SBEs' role in solving multiple problems in society}

This theme emerged as it appeared that many interviewees perceive the SBEs' role as multidimensional. Rather than focusing on a small range of societal problems, SBEs can contribute to many areas, as the following quotes show:

Social enterprise can play a significant role in the social sector and, at the same time, address environmental issues as well. We are a social business that is focused on recycling, but we also employ and train deprived youth how to make [an] indepndent living. (Interviewee 2)

We are a small landmass, and ecological sustainability is important for us. Reducing long-term risks associated with resource depletion, fluctuations in energy costs, pollution, and waste management create many opportunities for social entrepreneurs that also solve social problems such as employment. (Interviewee 9)

Environmental aspects have been part of our operations already since we started our business in 2005. It is only since last year that we have turned to solve social issues by providing job opportunities to deprived youth. (Interviewee 21)

The range of areas in which interviewees view possible contributions by SBEs is quite broad - from waste management and education to employment. Most often interviewees emphasised environmental concerns and lack of employment opportunities for younger people. Some SBEs aim to reintegrate the long-term unemployed into the labour market by employing them to produce products and offer services that are then sold in a competitive marketplace. Both concerns are noteworthy as they are economy-wide, rather than only 
affecting smaller, location-specific social problems, which the following excerpt also confirms:

Social issues are complex and affect in some way everyone in society, whether that is human safety, welfare, or community development. We need to build a partnership between social enterprises and the private and social sectors' organisations as well as the government. We all need to pool our resources and know-how to solve this and many other problems. (Interviewee 4)

This shows a broader role that SBEs could and need to play, in the interviewees' opinion, in Israeli society. Furthermore, this also aligns with a need for an ecosystem for SBEs and, once it is established, it is likely that the impact of social entrepreneurship on society will be quite significant, along multiple dimensions. According to a poll by the Thomson Reuters Foundation (2016) of some 900 SBE experts in the world's 45 largest economies, the top five countries for social entrepreneurism in order were the US, Canada, the UK, Singapore, and Israel. Although the scale of activity of socially focused ventures in Israel may be large compared to many other countries across the globe, the interviewees clearly believe that significantly more work could be done by SBEs and, in a variety of ways, they strongly confirmed that this is their expectation.

\section{Conclusion}

Applying the chosen theoretical framework, this study focuses on the impact of cosmopolitan orientation on the gap between prosperous and disadvantaged populations. The paper argues that the fundamental reason why the gap evolved and is increasing is in the discrepancy between novel and rapidly rising requirements presented by the innovation-focused economy compared to the workers' skills and their capacity to improve their skills. While the requirements for the skills are high and constantly advancing, some individuals are able to 
continuously upgrade their skillset and satisfy their employers' needs. In contrast, other individuals, owing to their low skills and, importantly, their low capacity to improve their skillset, appear unable to meet the employers' requirements. Keeping in mind that innovation-enabled growth was/is accompanied, as well as inspired, by the nation's cosmopolitan orientation, alongside other growth' drivers (Kakabadse and Mouraviev, 2019), the link between cosmopolitanism and ever-increasing requirements for workers' skills becomes evident.

Incorporating social entrepreneurship (Borzaga and Defourny, 2001) into the picture, the study shows that Israeli SBEs aim to bridge the gap between society's high expectations for innovation - driven by the government policy and established entrepreneurial and innovation ecosystem - and low capacity of certain populations to meet the requirements of innovative firms and entrepreneurs. The work of SBEs is a response to the downside of cosmopolitan orientation that contributed, alongside other enablers of economic growth, to the increasing disparity between those who had/have a higher capacity to align themselves with the requirements of a high-tech innovative economy (and, therefore, ensure a high living standard for themselves) and those who have lower capacity and, therefore, experience deprivation. Figure 2 summarises how the theoretical framework was applied in this study, emphasising the gap between prosperous populations and disadvantaged citizens, which SBEs work to reduce.

\section{< INSERT FIGURE 2 ABOUT HERE >}

Although some theorists (e.g. Li, 2020) argue that adjusting expectations for skills might be the solution for those with lower capacity, it is hardly the case of Israel. Alternatively, the discrepancy between skills and employers' expectations could be resolved by increasing 
workers' capacity to align their skills with the employers' requirements, which is the area to which Israeli SBEs contribute. Exemplified by the existence of a persistent and expanding gap between the rich and the poor despite sustainable economic growth, the discrepancy between skills and employers' requirements can be viewed as a feature of cosmopolitanism that accompanies growing economy and enhances growth, together with other factors. This is because society's expectations for innovation and for quality of human capital are constantly evolving, rather than set in stone. Therefore, meeting the ever-growing requirements of a dynamic, innovation-focused economy for knowledge and skills is an ongoing challenge that workers in Israel's cosmopolitan environment are facing, while Israeli SBEs are mitigating the most salient forms of this challenge affecting disadvantaged populations.

\section{Contribution, limitations, and suggestions for future research}

The paper contributes to the body of knowledge about SBEs by applying the framework that utilises the concept of cosmopolitan orientation (Mouraviev and Kakabadse, 2019), which helps to explain the growing gap between prosperous and disadvantaged populations, and identify the role of SBEs in reducing this gap. In Israel's context, the paper also delineates certain conditions (e.g. the need for coordinated actions, in unison with the government, the non-profit sector, and the donors; the need for clear legal status for SBEs; and the need for socially orientated investors in SBEs) that would ensure SBEs' more effective contribution to bridging the gap between prosperity and deprivation.

Findings of the study suggest that a cosmopolitan orientation perspective served, in part, as an enabler to Israel's economic growth and innovation. It emerged during liberalisation of Israeli economy and, alongside other enablers, it contributed to economic development by making use of global networks and attracting talent, ideas and technology from across the world. Part of economic development, which benefited from 
cosmopolitanism, is and has always been active entrepreneurship. Recognising the growing gap between prosperous and disadvantaged populations, many entrepreneurs adopted a social purpose as a guiding framework for their enterprises with the aim of mitigating social inequalities. Therefore, cosmopolitan orientation gave the impetus, although indirectly, to the development of social entrepreneurship.

The paper's important contribution is a finding that many SBEs focus not on alleviating income disparities but rather on disadvantaged populations' capacity and skill building. In addition, findings show that social entrepreneurs are becoming a leading force in mobilising private investment and government support to make social enterprises more sustainable. This is expected to be achieved by establishing more secure sources of funding (rather than relying on donors), drawing support from existing and new networks, enhancing SBEs' legitimacy, and shaping a more favourable public opinion of SBEs. The note about legitimacy is explained by the fact that many of the public sector's responsibilities are increasingly carried out in Israel by social enterprises instead of the government, and therefore SBEs need to be able to acquire a proper legal registration, which would not only acknowledge their status but also bring about greater acceptance from the public.

However, there is an inherent limitation in studying social entrepreneurship and cosmopolitanism using a relatively small qualitative sample within a unique context. Since the Israeli social entrepreneurs' population is relatively small, the sample size is limited. Therefore, the findings should be interpreted with caution. Furthermore, using the findings for making generalisations beyond Israel's setting may not be possible due to this nation's unique context.

Further research might address how poverty is dealt with by SBEs in other contexts to identify any commonalities and unique features of the selected countries. Of particular interest is investigation of the links between selected nations' cosmopolitan orientation and 
social entrepreneurship, and what SBEs focus on, and why, in those economies. The body of knowledge would benefit from future studies exploring SBEs and their possible contribution, if any, to bridging the prosperity-poverty gap within an internationally comparative context (e.g. in Ireland, Singapore, South Korea, Switzerland) using larger samples. In addition, in the future, researchers might use other empirical methods, such as case studies, focus groups, and surveys, to test this paper's model and findings.

\section{References}

Abbou, I., Gidron, B., David, N.B.-B., Greenberg, Y., Givon, Y.M. and Navon, A. (2017), "Social enterprise in Israel: the swinging pendulum between collectivism and individualism", Social Enterprise Journal, Vol. 13 No. 4, pp. 329-344.

Almog-Bar, M. (2016), "Policy initiatives towards the nonprofit sector: insights from the Israeli case", Nonprofit Policy Forum, Vol. 7 No. 2, pp. 237-256.

Anderson, A.R., Dodd, S.D. and Jack, S. (2010), "Network practices and entrepreneurial growth", Scandinavian Journal of Management, Vol. 26 No. 2, pp. 121-133.

Arendt, H. (2007), The Jewish Writings, Schocken, New York.

Atkinson, R. and Flint, J. (2004), "Snowball sampling”, in Lewis-Beck, M.S., Bryman, A. and Liao, L.F. (Eds.), The SAGE Encyclopaedia of Social Science Research Methods, Sage, London, pp. 245-261.

Bacq, S. and Janssen, F. (2011), "The multiple faces of social entrepreneurship: a review of definitional issues based on geographical and thematic criteria”, Entrepreneurship and Regional Development, Vol. 23 Nos. 5-6, pp. 373-403.

Bar-Shalom, Y.A., and Sarel, U. (2011), Change by Doing, Carmel Publishing, Jerusalem.

Ben-Porat, G. (2013), Between State and Synagogue: the Secularization of Contemporary Israel, Cambridge University Press, New York. 
Ben-Zion, Z. (2005), "From socialism to free market - the Israeli economy, 1948-2003", Israel Affairs, Vol. 11 No. 1, pp. 12-22.

Blaikie, N. (2009), Designing Social Research, Polity Press, Cambridge.

Bogdan, R.C. and Bilken, S.K. (1982), Qualitative Research for Education: an Introduction to Theory and Methods, Allyn and Bacon, Boston, MA.

Bohm-Duchen, M. (2013), "Marc Chagall: wandering Jew or citizen of the world", Jewish Quarterly, Vol. 32 No. 2, pp. 27-37.

Borzaga, C. and Defourny, J. (2001), The Emergence of Social Enterprise, Routledge, London and New York.

Bourdieu, P. (1984), Distinction: a Social Critique of the Judgement of Taste, Harvard University Press, Harvard.

CIA (Central Intelligence Agency) (2014), "The world factbook", available at: https://www.cia.gov/library/publications/the-world-factbook/rankorder/2172rank.html (accessed 14 December 2020).

Cohen, J. (1995), "Interpreting the notion of civil society", in Walzer, M. (Ed.) Toward a Global Civil Society, Berghahn Books, Oxford, pp. 35-40.

Cohen, H. and Katz, H. (2016), "Social entrepreneurs narrating their careers: a psychodynamic-existential perspective", Australian Journal of Career Development, Vol. 25 No. 2, pp. 78-88.

Cohen, H., Kaspi-Baruch, O. and Katz, H. (2019), "The social entrepreneur puzzle: the background, personality and motivation of Israeli social entrepreneurs", Journal of Social Entrepreneurship, Vol. 10 No. 2, pp. 211-231.

Cornfeld, O. and Danieli, O. (2015), “The origins of income inequality in Israel - trends and policy”, Israel Economic Review, Vol. 12 No. 2, pp. 51-95.

Cuonzo, M. (2014), Paradox, MIT Press, Cambridge, MA. 
Dacin, P.A., Dacin, M.T. and Matear, M. (2010), "Social entrepreneurship: why we don't need a new theory and how we move forward from here", Academy of Management Perspectives, Vol. 24 No. 3, pp. 37-57.

Dahan, M. (2017), "Income inequality in Israel: a distinctive evolution", CESifo Working Papers 6542, Ludwigs-Maximilians University's Center for Economic Studies, Germany, January, available at: https://www.ifo.de/DocDL/cesifo1_wp6542.pdf (accessed 8 May 2021).

Daniely, Y. (2020), “Global Innovation Index 2020: Chapter 12 - Israel's Challenging Transformation From Start-up Nation to Scale-Up Nation,” 2 September, available at: https://www.globalinnovationindex.org/gii-blog/2020/israel\%E2\%80\%99schallenging-transformation-from-start-up-nation-to-scale-up-nation--b231 (accessed 24 December 2020).

Dattel, L. (2017), "More Israelis left Israel than moved back in six year record", available at: https://www.haaretz.com/israel-news/.premium-more-israelis-left-israel-than-movedback-data-reveals-1.5442809 (accessed 18 November 2020).

De Clercq, D. and Voronov, M. (2009), "The role of cultural and symbolic capital in entrepreneurs' ability to meet expectations about conformity and innovation", Journal of Small Business Management, Vol. 47 No. 3, pp. 398-420.

Dees, J.G. (2003), "Social entrepreneurship is about innovation and impact, not income", Durham, NC: Center for the Advancement of Social Entrepreneurship. Fuqua School of Business, Duke University, available at: https://centers.fuqua.duke.edu/case/knowledge_items/social-entrepreneurship-isabout-innovation-and-impact-not-income/ (accessed 17 December 2020).

Douzinas, C. (2007), Human Hights and Empire: the Political Philosophy of Cosmopolitanism, Routledge-Cavendish, New York. 
Drori, I., Honig, B. and Wright, M. (2009), "Transnational entrepreneurship: an emergent field of study", Entrepreneurship Theory and Practice, Vol. 33 No. 5, pp. 1001-1022.

Etikan, I., Musa, S.A. and Alkassim, R.S. (2016), “Comparison of convenience sampling and purposive sampling", American Journal of Theoretical and Applied Statistics, Vol. 5 No. 1, pp. 1-4.

Flick, U. (2018), An Introduction to Qualitative Research, Sage, London.

Gappert, G. (1989), “Global thinking and urban planning”, in Knight, R.V. and Gappert, G. (Eds.) Cities in Global Society, Sage, Newbury Park, pp. 305-325.

Gidron, B. and Abbou, I. (2012), "The phenomenon of social businesses: some insight from Israel”, in Gidron, B. and Hasenfeld, Y. (Eds.) Social Enterprises: an Organisational Perspective, Palgrave Macmillan, London, pp. 144-161.

Gidron, B., Abbou, I., Buber, N. and Greenberg, Y. (2013), "Social enterprise in Israel: the swinging pendulum between collectivism and individualism", ICSEM Working Papers, No. 20, International Comparative Social Enterprise Models (ICSEM), Belgium.

Gidron, B., Bar, M. and Katz, H. (2004), The Israeli Third Sector: Between Welfare State and Civil Society, Springer, New York.

Gold, S.J. (2001), “Gender, class, and network: social structure and migration patterns among transnational Israelis", Global Networks, Vol. 1 No. 1, pp. 19-40.

Hahn, T. and Knight, E. (2019), “The ontology of organizational paradox: a quantum approach", Academy of Management Review, available at: https://doi.org/10.5465/amr.2018.0408 (accessed 8 November 2020).

Honig, B., Drori, I. and Carmichael, B. (Eds.) (2010), Transnational and Immigrant Entrepreneurship in a Globalized World, University of Toronto Press, Toronto. 
IMF (International Monetary Fund) (2021), World Economic Outlook Databases, available at: $\quad$ https://www.imf.org/en/Publications/SPROLLs/world-economic-outlookdatabases\#sort=\%40imfdate\%20descending (accessed 10 May 2021).

Kakabadse, N. and Mouraviev, N. (2019), "From sand dunes northward of Jaffa to a cosmopolitan city: Tel Aviv entrepreneurs' experiences", in Mouraviev, N. and Kakabadse, N. (Eds.), Entrepreneurship and Global Cities: Diversity, Opportunity and Cosmopolitanism, Routledge, New York, pp. 48-69.

Kakabadse, N.K., Figueira, C., Nicolopoulou, K., Hong Yang, J., Kakabadse, A.P. and Ozbilgin, M.F. (2015), “Gender diversity and board performance: women's experiences and perspectives", Human Resource Management, Vol. 54 No. 2, pp. 265-281.

Kroeger, A. and Weber, C. (2014), "Developing a conceptual framework for comparing social value creation", Academy of Management Review, Vol. 39 No. 4, pp. 513-540.

Leef, D. (2011), "State of emergency, bring a tent and take a stand", available at: www.facebook.com/events/114332568661646/ (accessed 3 January 2021).

Levy, N. (2001), “Against philanthropy, individual and corporate”, Business and Professional Ethics Journal, Vol. 21 Nos. 3/4, pp. 95-108.

Li, X. (2020), “Quantum approach to organizational paradox: a Copenhagen perspective", Academy of Management Review, available at: https://doi.org/10.5465/amr.2019.0480 (accessed 5 January 2021).

Lincoln, Y.S. and Guba, E.G. (1985), Naturalistic Inquiry, Sage Publications, Newbury Park, CA.

Lofland, J. (1971), Analysing Social Settings, Wadsworth, Belmont, CA. 
Malach, G. and Cahaner, L. (2019), "Statistical report on ultra-orthodox society in Israel: highlights", the Israeli Democracy Institute, available at: https://en.idi.org.il/articles/29348 (accessed 5 January 2021).

Malul, M. (2018), "The economy of Israel", presentation, Ben-Gurion University of the Negev, October.

Marom, N. (2013), “Activising space: the spatial politics of the 2011 protest movement in Israel”, Urban Studies, Vol. 50 No. 13, pp. 2826-2841.

Martin, R.L. and Osberg, S. (2007), "Social entrepreneurship: the case for definition", Stanford Social Innovation Review, Vol. 5 No. 2, pp. 28-39.

Miles, M.B. and Huberman, A.M. (1994), Qualitative Data Analysis: an Expanded Sourcebook (2nd ed.), Sage, Thousand Oaks, CA.

Mouraviev, N. and Kakabadse, N. (2016), "Conceptualising cosmopolitanism and entrepreneurship through the lens of the three-dimensional theory of power", Society and Business Review, Vol. 11 No. 3, pp. 242-256.

Mouraviev, N. and Kakabadse, N. (Eds.) (2019), Entrepreneurship and Global Cities: Diversity, Opportunity and Cosmopolitanism, Routledge, New York.

NII (National Insurance Institute) (2018), "National Insurance programs in Israel”, available at https://www.btl.gov.il/English\%20Homepage/Publications/Insurance\%20Programs/D ocuments/charth18-e.pdf (accessed 23 October 2020).

OECD (2020), Economic Surveys Israel, available at: https://www.oecd.org/economy/surveys/Israel-2020-OECD-economic-surveyoverview.pdf (accessed 10 May 2021).

Plotnitsky, A. (2013), Niels Bohr and Complementarity: an Introduction, Springer, New York. 
Quelin, B.V., Kivleniece, I. and Lazzarini, S.G. (2017), "Public-private collaboration, hybridity and social value: towards new theoretical perspectives", Journal of Management Studies, Vol. 54 No. 6, pp. 763-792.

Reed, J. (2015), “Unit 8200: Israel’s cyber spy agency”, Financial Times, 10 July, available at: https://www.ft.com/content/69f150da-25b8-11e5-bd83-71cb60e8f08c (accessed 10 May 2021).

Roper, S. and Grimes, S. (2005), "Wireless Valley, Silicon Wadi and Digital Island Helsinki, Tel Aviv and Dublin and the ICT global production network", Geoforum, Vol. 36 No. 3, pp. 297-313.

Rothschild, J. (2009), "Workers' cooperatives and social enterprise: a forgotten route to social equity and democracy", American Behavioral Scientist, Vol. 52 No. 7, pp. 1023-1041.

Senor, D. and Singer, S. (2009), Start-up Nation: the Story of Israel's Economic Miracle, Hachette Book Group, New York.

Shaoul, J. (2020), "Israel's deepening poverty, social inequality ignored in election campaign”, International Committee of the Fourth International (ICFI), 29 February, available at: https://www.wsws.org/en/articles/2020/02/29/isra-f29.html (accessed 15 January 2021).

Singh, A.A., Hays, D.G. and Watson, L.S. (2011), "Strength in the face of adversity: Resilience strategies of transgender individuals", Journal of Counselling \& Development, Vol. 89 No. 1, pp. 20-27.

Skrbiš, Z. and Woodward, I. (2013), Cosmopolitanism: Uses of the Idea, Sage, London.

Strauss, A.L. and Corbin, J. (2008), Basics of Qualitative Research: Grounded Theory Procedures and Techniques, SAGE Publications, London.

Svirsky, S. (2013), Social Point of View, Adva Centre, Tel Aviv. 
Sznaider, N. (2007), "Hannah Arendt's Jewish cosmopolitanism between the universal and the particular", European Journal of Social Theory, Vol. 10 No. 1, pp. 112-122.

Sznaider, N. (2010), "A Jewish comment on cosmopolitan citizenship in the Middle East", Open Democracy, 10 August, available at: https://www.opendemocracy.net/en/jewish-comment-on-cosmopolitan-citizenship-inmiddle-east/ (accessed 15 May 2021).

Thompson, J., Alvy, G. and Lees, A. (2000), "Social entrepreneurship - a new look at the people and the potential”, Management Decision, Vol. 38 No. 5, pp. 328-338.

Thomson Reuters Foundation (2016), "The best countries to be a social entrepreneur 2016", available at: http://poll2016.trust.org (accessed 29 September 2020).

Tzfadia, E. and Yacobi, H. (2011), Rethinking Israeli Space, Routledge, London.

Waksman, A. (2018), "Israeli income inequality lowest in 20 Years", Haaretz, 17 December, available at: https://www.haaretz.com/israel-news/business/israeli-income-inequalitylowest-in-20-years-1.6743249 (accessed 7 May 2021).

WEF (World Economic Forum) (2017), Global Competitiveness Report 2026-2017, available at: https://innovationisrael.org.il/en/contentpage/innovation-israel (accessed 10 May 2021).

WEF (World Economic Forum) (2020), "These countries spend the most on research and development”, $\quad 16 \quad$ November, available at: https://www.weforum.org/agenda/2020/11/countries-spending-research-developmentgdp/ (accessed 15 May 2021).

Woodward, I., Skrbiš, Z. and Bean, C. (2008), "Attitudes toward globalisation and cosmopolitanism: cultural diversity, personal consumption and the national economy", The British Journal of Sociology, Vol. 59 No. 2, pp. 207-226. 
Table 1. Interviewee profile

\begin{tabular}{|c|c|c|c|c|c|}
\hline $\begin{array}{c}\text { Identifier } \\
\text { (interviewee) }\end{array}$ & Gender & Role & $\begin{array}{l}\text { Years } \\
\text { in role }\end{array}$ & Industry & Type of the SE \\
\hline 1 & $\mathrm{M}$ & Co-founder & 2 & Hospitality, education & Cooperative \\
\hline 2 & $\mathrm{M}$ & Co-founder & 4 & Recycling & Social business \\
\hline 3 & M & Manager & 3 & Education services & Not-for-profit \\
\hline 4 & $\mathrm{~F}$ & Co-founder & 1 & Community programmes & Cooperative \\
\hline 5 & $\mathrm{M}$ & Founder & 1 & Social empowerment & Not-for-profit \\
\hline 6 & $\mathrm{~F}$ & Co-founder & 1 & Disability inclusion & Not-for-profit \\
\hline 7 & M & Manager & 2 & Delivery service & Not-for-profit \\
\hline 8 & M & Co-founder & 2.5 & Disability inclusion & Cooperative \\
\hline 9 & $\mathrm{~F}$ & Co-founder & 3 & Shared workspaces & Social business \\
\hline 10 & $\mathrm{M}$ & Manager & 2 & Hospitality & Cooperative \\
\hline 11 & M & Co-founder & 1 & Culture & Social business \\
\hline 12 & $\mathrm{M}$ & Founder & 2 & Rehabilitation & Not-for-profit \\
\hline 13 & $\mathrm{~F}$ & Manager & 3 & Sustainability & Social business \\
\hline 14 & M & Co-founder & 2 & Shared spaces & Social business \\
\hline 15 & M & Manager & 1.5 & Community programmes & Not-for-profit \\
\hline 16 & $\mathrm{M}$ & Co-founder & 2.4 & Delivery service & Not-for-profit \\
\hline 17 & $\mathrm{~F}$ & Co-founder & 2 & Culture & Not-for-profit \\
\hline 18 & $\mathrm{M}$ & Co-founder & 1 & Sustainability & Not-for-profit \\
\hline 19 & $\mathrm{~F}$ & Founder & 3 & Technology & Social business \\
\hline 20 & $\mathrm{~F}$ & Co-founder & 2.4 & Technology & Social business \\
\hline 21 & M & Manager & 2 & Spaces for rent & Social business \\
\hline 22 & M & Co-founder & 2.6 & Delivery service & Not-for-profit \\
\hline 23 & M & Co-founder & 2 & Social empowerment & Not-for-profit \\
\hline
\end{tabular}

Source: Compiled by the authors. 
Table 2. Drawing from the data: categories and themes

\begin{tabular}{|c|c|c|}
\hline Empirical data & $\begin{array}{l}\text { Conceptual } \\
\text { categories }\end{array}$ & $\begin{array}{c}\text { Broader } \\
\text { themes }\end{array}$ \\
\hline $\begin{array}{l}\text { 'You just need to look around you to see a need. Our } \\
\text { government is doing less and less for people in need' } \\
\text { (Interviewee 7) }\end{array}$ & \multirow[t]{2}{*}{$\begin{array}{l}\text { The need for } \\
\text { social } \\
\text { entrepreneurship }\end{array}$} & \multirow{6}{*}{$\begin{array}{l}\text { Cosmopolitan } \\
\text { predisposition }\end{array}$} \\
\hline $\begin{array}{l}\text { 'I had this vision when I was in high school. From an early } \\
\text { age, I saw this enormous need to make changes. So, I had to } \\
\text { try to solve the problem. Now communities aboard can use } \\
\text { this tool - it is for everyone' (Interviewee 1) }\end{array}$ & & \\
\hline $\begin{array}{l}\text { 'I cannot be simultaneously happy and at the same time } \\
\text { ignore the others in need. Seeing the positive change my } \\
\text { work brings is highly motivating' (Interviewee 19) }\end{array}$ & \multirow[t]{2}{*}{$\begin{array}{l}\text { Motivation for } \\
\text { starting a social } \\
\text { enterprise }\end{array}$} & \\
\hline $\begin{array}{l}\text { '... creating opportunity for others to develop and changing } \\
\text { lives is what keeps me going' (Interviewee 2) }\end{array}$ & & \\
\hline $\begin{array}{l}\text { 'My social consciousness was born out of my upturning and a } \\
\text { habit to help others' (Interviewee 14) }\end{array}$ & \multirow[t]{2}{*}{ Habitus } & \\
\hline $\begin{array}{l}\text { 'Throughout my schooling I was always volunteering and } \\
\text { helping others. .... My habit has become a formal enterprise' } \\
\text { (Interviewee 6) }\end{array}$ & & \\
\hline $\begin{array}{l}\text { 'A traditional form of a cooperative, Kibbutzim has lost its } \\
\text { legitimacy in the eyes of the public, although in the1980s } \\
\text { there was a new movement that established a several urban } \\
\text { Kibbutzim. Our cooperative challenges this misconception as } \\
\text { it attracts resources to those in needs' (Interviewee 18) }\end{array}$ & \multirow[t]{2}{*}{$\begin{array}{l}\text { Build legitimacy } \\
\text { and combine two } \\
\text { sides of SE }\end{array}$} & \multirow{6}{*}{ SE purpose } \\
\hline $\begin{array}{l}\text { 'Gaining public trust, building reputation and growing is } \\
\text { challenging as we are still in an embryonic state' (Interviewee } \\
\text { 5) }\end{array}$ & & \\
\hline $\begin{array}{l}\text { 'If I did not think that it is possible to bridge this gap, would I } \\
\text { be doing what I am doing today?' (Interviewee 17) }\end{array}$ & \multirow{2}{*}{$\begin{array}{l}\text { Bridge the gap } \\
\text { between the rich } \\
\text { and the poor }\end{array}$} & \\
\hline $\begin{array}{l}\text { 'The rich-poor divide needs to be minimised, and we need } \\
\text { more people, from all sectors, to be involved' (Interviewee } \\
\text { 20) }\end{array}$ & & \\
\hline $\begin{array}{l}\text { 'In many ways we are solving a number of problems, finding } \\
\text { resources and skills and putting them to good use, and at the } \\
\text { same time we educate and train those in need, as well as we } \\
\text { use suitable resources' (Interviewee 16) }\end{array}$ & \multirow[t]{2}{*}{$\begin{array}{l}\text { Solve multiple } \\
\text { problems in } \\
\text { society }\end{array}$} & \\
\hline $\begin{array}{l}\text { 'Our aim is to help those in need, and we do so in } \\
\text { environmentally sustainable manner' (Interviewee 29) }\end{array}$ & & \\
\hline
\end{tabular}

Source: Compiled by the authors. 
Table 3. Three forms of Israeli social enterprises

\begin{tabular}{|c|c|c|c|}
\hline Characteristics & SE as Social business & $\begin{array}{c}\text { SE as Non-profit } \\
\text { organisation }\end{array}$ & SE as Cooperative \\
\hline Governance & $\begin{array}{l}\text { One or more } \\
\text { entrepreneurs }\end{array}$ & $\begin{array}{l}\text { Participatory } \\
\text { governance }\end{array}$ & $\begin{array}{l}\text { Democratic } \\
\text { governance involving } \\
\text { stakeholders }\end{array}$ \\
\hline Ownership & Independent & $\begin{array}{l}\text { Established by an } \\
\text { organisation; led by } \\
\text { voluntary board }\end{array}$ & $\begin{array}{l}\text { Established by a } \\
\text { group; collective } \\
\text { ownership }\end{array}$ \\
\hline Initial funding & $\begin{array}{l}\text { Private equity; loans } \\
\text { and investors }\end{array}$ & Philanthropy & $\begin{array}{l}\text { Membership fees and } \\
\text { share purchase }\end{array}$ \\
\hline Ongoing funding & $100 \%$ sales & Sales and donations & Sales \\
\hline Profit & $\begin{array}{l}\text { Belongs to the } \\
\text { owner(s) or } \\
\text { shareholders }\end{array}$ & $\begin{array}{l}\text { Is invested in social } \\
\text { cause }\end{array}$ & $\begin{array}{l}\text { Belongs to group } \\
\text { members }\end{array}$ \\
\hline $\begin{array}{l}\text { Tendency in risk- } \\
\text { taking }\end{array}$ & High risk & Low risk & Medium risk \\
\hline Social mission & $\begin{array}{l}\text { Emphasis on profit and } \\
\text { social mission that can } \\
\text { provide a competitive } \\
\text { advantage (e.g. } \\
\text { improving } \\
\text { environment or } \\
\text { creating jobs) }\end{array}$ & $\begin{array}{l}\text { A wide variety of } \\
\text { social missions (e.g. } \\
\text { contribution to culture, } \\
\text { education, } \\
\text { employment, } \\
\text { rehabilitation) }\end{array}$ & $\begin{array}{l}\text { Priority given to } \\
\text { social mission, such } \\
\text { as social activities } \\
\text { and consumption }\end{array}$ \\
\hline Appeals to & $\begin{array}{l}\text { Self-driven individuals } \\
\text { (most energetic } \\
\text { individuals within } \\
\text { marginalised } \\
\text { populations) }\end{array}$ & $\begin{array}{l}\text { Socially conscious } \\
\text { individuals (can } \\
\text { accommodate a } \\
\text { broader spectrum of } \\
\text { marginalised } \\
\text { populations) }\end{array}$ & $\begin{array}{l}\text { Socially conscious } \\
\text { individuals }\end{array}$ \\
\hline $\begin{array}{l}\text { Target } \\
\text { population }\end{array}$ & Society at large & $\begin{array}{l}\text { Marginalised } \\
\text { population }\end{array}$ & $\begin{array}{l}\text { Socially } \\
\text { disadvantaged }\end{array}$ \\
\hline Major challenges & $\begin{array}{l}\text { Business side may be } \\
\text { taking over the social } \\
\text { side. Revenue is } \\
\text { required to cope with } \\
\text { the social issues }\end{array}$ & $\begin{array}{l}\text { Financial activity } \\
\text { needs to relate to the } \\
\text { social core. } \\
\text { Professional business } \\
\text { management is } \\
\text { required }\end{array}$ & $\begin{array}{l}\text { Effective decision- } \\
\text { making and } \\
\text { management are } \\
\text { needed. A } \\
\text { cooperative requires } \\
\text { membership fees that } \\
\text { might exclude } \\
\text { marginalised or } \\
\text { poorer populations }\end{array}$ \\
\hline
\end{tabular}

Source: Compiled by the authors from Defourny and Nyssens (2012) and Gidron et al. (2013). 
Figure 1. Study's theoretical framework

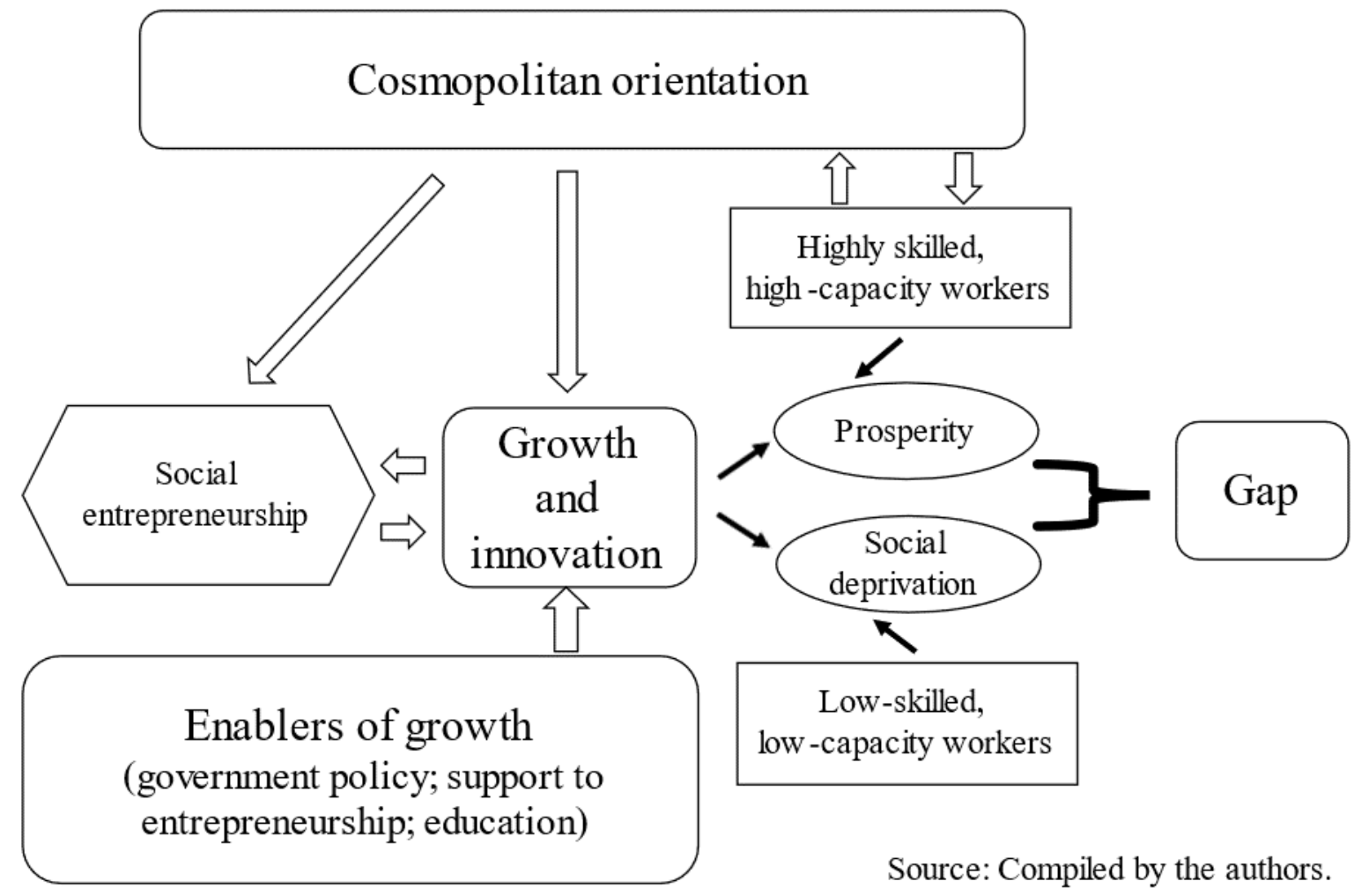

Figure 2. Application of study's theoretical framework

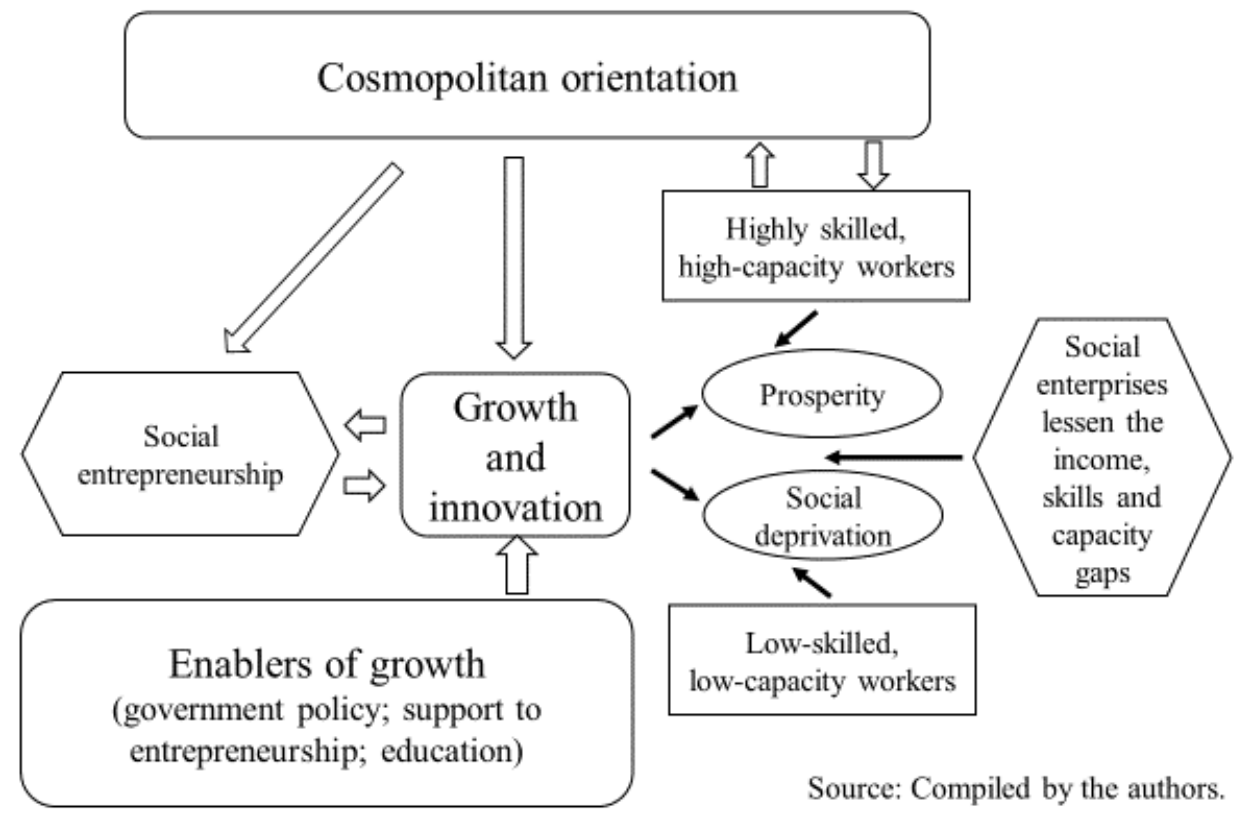

